\title{
GLUCOSE HOMEOSTATIC AND PANCREAS PROTECTIVE POTENTIAL OF TECOMELLA UNDULATA ROOT EXTRACT IN STREPTOZOTOCIN-INDUCED DIABETIC RATS
}

\author{
KANWAR LAL, ASHOK PUROHIT, HEERA RAM
}

Department of Zoology, Jai Narain Vyas University, Jodhpur, Rajasthan, India. Email: baradhr@gmail.com, klgenwa21@gmail.com

Received: 18 February 2016, Revised and Accepted: 27 March 2017

\begin{abstract}
Objective: The study was aimed to evaluate glucose homeostatic and pancreas protective potential of Tecomella undulata root extract in streptozotocin induced diabetic rats.

Methods: The ethanolic root extract was prepared by following standard soxhlation methods. The experimental design was divided in to control and treated groups for 28 days of comparative experimental schedule. The body and organ weights, serum biochemistry, histo-pathology, hematology and toxicity profiles were assayed by following standard methods and protocols.
\end{abstract}

Results: The treatment of ethanolic extract of root of $T$. undulata was significantly ( $p \leq 0.001)$ reduced glucose levels at 7 day, 14 day, 21 day and 28 days in comparison to standard drug of metformin. Correspondingly, lipid profile i.e. total cholesterol, HDL, VLDL, LDL and triglyceride were also altered significantly. Whereas, body and organs weight and hematological parameters were not shown significant changes. Subsequently, toxicity profile i.e. hepatic and renal parameters were remained under normal ranges. Corresponding, the treatment of ethanolic root extract caused normalcy of histoarchitecture of pancreas in comparison to standard drugs.

Conclusion: The results of study illustrated that Tecomella undulata root extract possessing particular kind of phytocompounds which caused glucose homeostatic and pancreas protective potential in diabetic rats.

Keywords: Diabetes, Glucose homeostatic potential, Pancreasprotective, Histopathology, Glucose levels, Ticomella undulata root extract.

(C) 2017 The Authors. Published by Innovare Academic Sciences Pvt Ltd. This is an open access article under the CC BY license (http://creativecommons. org/licenses/by/4. 0/) DOI: http://dx.doi.org/10.22159/ajpcr.2017.v10i6.17997

\section{INTRODUCTION}

Diabetes is an endocrine, metabolic disease which is clinically characterized by chronic hyperglycemia due to poor insulin availability. The etiology of diabetes can be inducing pathological damage to the liver, kidneys, and pancreas, with characteristic abnormalities in the metabolism of carbohydrates, lipids, and proteins [1-3]. Whereas there are several kinds of therapeutic approaches for diabetes, but associated side effects pointed out to rethink. Behind this, the ancient Indian medical system of the Ayurveda having peculiar kind of therapeutic patterns which shown minimum drug-associated side effects those are mainly based on herbal formulation. Herbal formulations have been existed worldwide with long documented history and used in various civilizations, i.e., ancient Chinese, Greek, Egyptian, and Indian for several remedies determinations [4-11]. The World Health Organization estimated that $80 \%$ of the word's populations still depend on traditional medicines for their health problems. Whereas the Indian subcontinent is a renowned to be one of the major biodiversity center with about 45,000 plant varieties. In India, about 15,000 medicinal floras have been noted, and up to 7,000-7,500 plants are used by communities for therapeutics of various kinds of ailments $[11,12]$.

In similar kind of view, western Rajasthan (Part of the Thar desert) having peculiar kind of medicinal plants which are used by local people from long back based on conventional wisdom for therapeutics of diabetes and other diseases $[5,12,13]$. The local desert plants having a huge and unique number of secondary metabolites and phytocompounds through the specific stress conditions of desert. Even Rajasthan state having their own state flower, i.e., Tecomella undulate is rich source of numerous valued bioactive phytocompounds. Whereas, the various parts of T. undulata are also used for various ailments. The root and bark possessing some peculiar kinds of phytocompounds, i.e., radermachol, lapachol, tecomaquinone-I, $\alpha$-lapachone, $\beta$-lapachone, stigmasterol, $\beta$-sitosterol, oleanolic acid, ursolic acid, and betulinic acid which are prescribing in the Ayurveda practices and available in market $[14,15]$. The various parts of $T$. undulate have also been used in the curing of syphilis, painful swellings, antibacterial, hepatoprotective, immunomodulatory, and anti-inflammatory activities [16-20]. However, the root of this plant is main part which directly exposed to climatic stress conditions having an abundance of bioactive phytocompounds. Therefore, this effort was made to assess glucose homeostatic, and pancreas-protective potential of ethanolic root extract of Tecomella undulate through investigations of body and organs weights, serum biochemistry, histopathology of pancreas and hematology.

\section{METHODS}

Chemicals

Required chemicals and reagents were obtained from local Loba chemie suppliers, and test kits (Erba) were also used for biochemical analyses.

Collection and extraction of chosen plant material

The roots parts of T. undulata were collected from in and around university new campus which were authenticated by taxonomist of botany, department of botany.

The dried root was grinded and soxhalated in $70 \%$ ethanol for $18 \mathrm{hrs}$ at $72^{\circ} \mathrm{C}$ temperature. The prepared extract was dried and used as per routine protocol [21].

\section{Dose of extract and drug}

The dose regime of extract and drug were allocated for oral administration, i.e., $500 \mathrm{mg} / \mathrm{kg}$ body weight for 28 days in comparison to metformin at the dose of $100 \mathrm{mg} / \mathrm{kg} / \mathrm{d}$. 
Experimental animal

Adult albino rats (Rattus norvegicus) weighing of 170-250 g were obtained from the animal house of Indian Veterinary Research Institute, Briley, UP. The animals were kept under standard environmental situations, i.e., $12 \mathrm{hrs}$. light and dark cycles with optimal temperature conditions of $24-28^{\circ} \mathrm{C}$. The feeding and diet were maintained as per recommendations of the Veterinarian advice with the proper proportion of nutrients and vitamins along with a supply of drinking water ad libitum. While animal experimental protocols were permitted by Institutional Animal Ethical Committee (Reg. No: 1646/GO/ $\mathrm{ERe} / \mathrm{S} / 12 / \mathrm{CPCSEA})$.

\section{Diabetes induction}

The induction diabetes by following our laboratory protocol as single IP inoculation of streptozotocin (STZ) (Sigma-Aldrich, Mumbai, India) dissolved in $0.01 \mathrm{M}$ sodium citrate buffer ( $\mathrm{pH} 4.5$ ), and managed at a dose of $55 \mathrm{mg} / \mathrm{kg}$ in overnight fasted animals [22].

\section{Experimental design}

Diabetic animals were subjectively arranged into four groups and an individual group consisting of seven animals to control and experimental groups for respective treatment for 28 days.

- Group 1: Vehicle control.

- Group 2: Diabetic control

- Group 3: Diabetic + T. undulate root extract (500 mg/kg b.w.) for 28 days.

- Group 4: Diabetic + metformin $(100 \mathrm{mg} / \mathrm{kg} / \mathrm{d})$ for 28 days.

\section{Serum biochemistry assessments}

The glucose variations at different days, related lipid profile (triglyceride, total cholesterol, high-density-lipoprotein-cholesterol, low-density lipoprotein [LDL]-cholesterol, very LDL [VLDL] - cholesterol, and other indices) and toxicology profile, i.e., urea, uric acid, creatinine, serum glutamic oxaloacetic transaminase (SGOT), serum glutamatepyruvate transaminase (SGPT), alkaline phosphatase, bilirubin, total protein, albumin, and globulin were evaluated from serum using commercial supplied biological Erba kits (glucose oxidase-peroxidase methods) [23-25].

\section{Hematological analysis}

Red blood corpuscle (RBC) counts, hemoglobin content, total leukocyte cells, platelets (thrombocytes) count, and other related parameters of hematology were calculated by standard methods [26].

\section{Histopathological investigations}

The histopathology specimens of the pancreas were made by following standard protocol of our laboratory. The paraffin sections were stained by hematoxylin-eosin and microphotography made by camera attached microscope to study pancreas-protective changes in histoarchitectures of pancreas in control and treated animals [27-29].

\section{Statistical analysis}

All values of biochemistry, hematology, body and organs weights were evaluated by one-way ANOVA, followed through Dunnett test using software Sigma-Sat trial version. In all the tests, the criteria of statistical significance were $\mathrm{p} \leq 0.005$.

\section{RESULTS}

The treatment of root extract of $T$. undulata caused significant alterations in treated experimental groups in comparison to metformin treatment and diabetic control as shown in following results.

\section{Body and organs weights}

The root extract of $T$. undulate showed a non-significant reduction in body weight, pancreas, and liver. Whereas other morphological signs were shown fatigue and less activeness in diabetic rats in comparison to treated and vehicle control (Table 1).

\section{Serum biochemistry}

a. The treatment of root extract of $T$. undulata revealed significant $(\mathrm{p} \leq 0.001)$ gradual decreases in glucose levels in comparison to metformin at 7 days, 14 days, 21 days, and 28 days with diverse grades. However, significant raised glucose level was observed in diabetic rats up to $250-350 \mathrm{mg} / \mathrm{dl}$ (Fig. 1).

b. Accordingly, the lipid profile, i.e., total cholesterol, LDL- cholesterol, triglyceride, and VLDL-cholesterol were significantly $(p \leq 0.001)$ decreased in treated animals as a comparison to diabetic control (Table 2).

c. Compassionately, toxicity profile, i.e., creatinine, urea, uric acid, SGOT, SGPT, alkaline phosphatase, bilirubin total protein, albumin, and globulin were endured under and around normal ranges (Fig. 2).

\section{Haematology}

RBC count, total leukocytes count, platelets count, and other related morphological parameters were not altered significantly in treated groups (Fig. 3).

\begin{abstract}
Histopathology
The pancreatic histoarchitecture of vehicle control consisting of condensed, lobulated compounds of tubuloacinar gland of exocrine and endocrine part with distinguished symmetry. The islets, i.e., endocrine part exhibiting of diverse sizes and surrounded inside the exocrine tissue of pancreas with bright staining. There were three diverse categories of islets seen, i.e., small, medium, and large sized were distinguished. Individually, islet was consisting of alpha, beta, delta, and pancreatic polypeptide cells embedded in peripheral tissues of acini and vessels (Fig. 4). Whereas, diabetic pancreatic histology showed vacuolization and deterioration in islet cells with congestion of RBC. The diabetic pancreas correspondingly exhibited indiscretions in peripheral exocrine parts and vascular part (Fig. 5).
\end{abstract}

However, the treatment of root extract of T. undulate encouraged rearchitecture of islet as well as the reorganization of peripheral tissues (Fig. 6). Correspondingly, the treatment of metformin revealed near to normalcy of islet with existing of cells and proper arrangement of peripheral tissues (Fig. 7).

\section{DISCUSSION}

Hyperglycemia and non-functional pancreatic $\beta$-cell are considered as a diabetic pathological condition from primary description [30,31]. Whereas there are several kinds of pharmacological approaches for

Table 1: Effect on body and organs weight of root extract of $T$. undulata in STZ-induced diabetic albino rats (mean of 5 values SEM)

\begin{tabular}{|c|c|c|c|c|c|c|}
\hline \multirow[t]{2}{*}{ Group } & \multicolumn{2}{|c|}{ Mean body weight (gm) } & Heart & Pancrea & Kidney & \multirow{2}{*}{$\begin{array}{l}\text { Liver } \\
\text { g/100 g body weight }\end{array}$} \\
\hline & Initial & Final & \multicolumn{3}{|c|}{ mg/100gm body weight } & \\
\hline Group I (vehicle control) & $203.13 \pm 3.13$ & $209.23 \pm 7.17$ & $469.12 \pm 07.33$ & $231.21 \pm 21.17$ & $581.09 \pm 31.11$ & $4.93 \pm 0.31$ \\
\hline Group II (diabetic control) & $199.11 \pm 7.01$ & $193.11 \pm 10.02^{\mathrm{c}}$ & $453.17 \pm 13.11^{\mathrm{d}}$ & $178.17 \pm 31.10^{c}$ & $511.31 \pm 22.07^{d}$ & $4.13 \pm 0.23^{c}$ \\
\hline $\begin{array}{l}\text { Group III ( } T \text {. undulata root } \\
\text { extract treatment) }\end{array}$ & $210.01 \pm 9.11$ & $201.12 \pm 7.11^{\mathrm{d}, \mathrm{h}}$ & $467.21 \pm 11.23^{\mathrm{d}, \mathrm{h}}$ & $203.21 \pm 17.11^{\mathrm{c}, \mathrm{g}}$ & $563.33 \pm 31.11^{\mathrm{d}, \mathrm{h}}$ & $4.41 \pm 0.11^{\mathrm{d}, \mathrm{h}}$ \\
\hline Group IV (metformin & $211.7 \pm 7.01$ & $203.01 \pm 9.21^{\mathrm{d}, \mathrm{h}}$ & $471.70 \pm 19.01^{\mathrm{d}, \mathrm{h}}$ & $201.19 \pm 19.13^{c, g}$ & $577.23 \pm 17.31^{\mathrm{d}, \mathrm{h}}$ & $4.89^{\mathrm{d}, \mathrm{h}} \pm 0.21^{\mathrm{d}, \mathrm{h}}$ \\
\hline
\end{tabular}

treatment)

Data are means \pm SEM. $(\mathrm{n}=7),{ }^{\mathrm{c}} \mathrm{p} \leq 0.001,{ }^{\mathrm{d}}$ non-significant as compared to the respective control values, ${ }^{\mathrm{g}} \mathrm{p} \leq 0.001$, and ${ }^{\mathrm{h}}$ non-significant as compared to the respective values of the diabetic control group, T. undulate: Tecomella undulate, STZ: Streptozotocin 


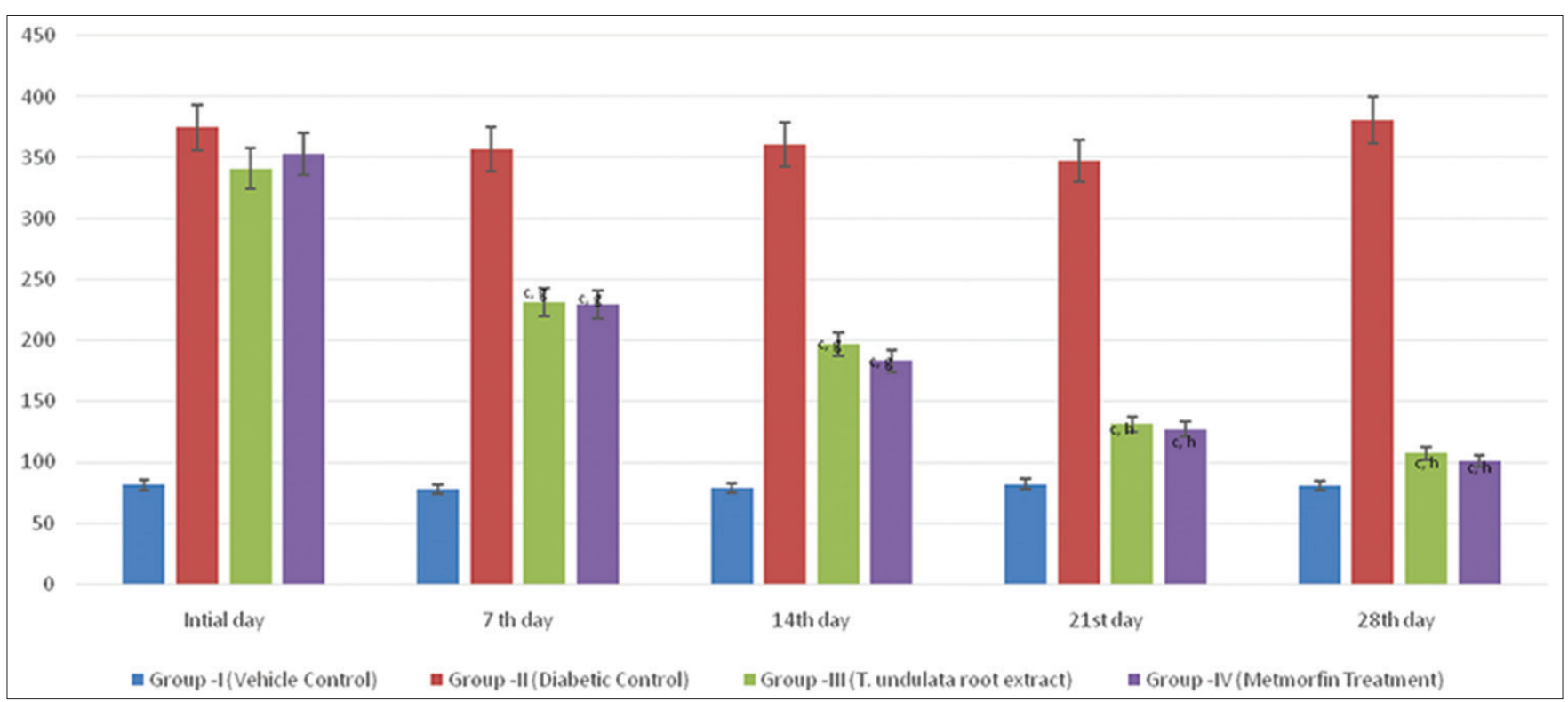

Fig. 1: Effect of Tecomella undulate root extract on glucose levels in streptozotocin induced diabetic albino rats. Data are Mean \pm standard error mean SEM ( $n=7),{ }^{c} p \leq 0.001$, ${ }^{d}$ non-significant as compared to the respective control values, ${ }^{g} p \leq 0.001$, and ${ }^{\text {h}}$ non-significant as compared to the respective values of the diabetic control group

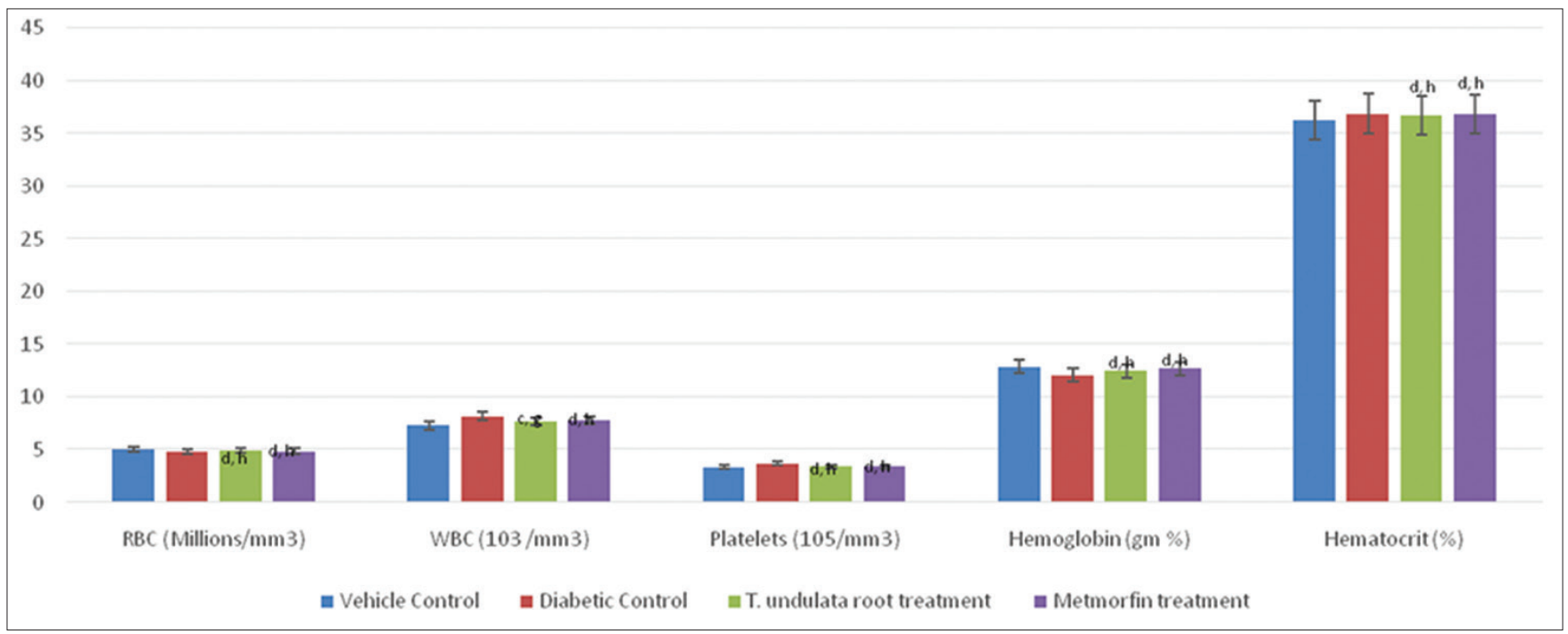

Fig. 2: Effect of Tecomella undulate root extract on renal and liver function indices in streptozotocin induced diabetic albino rats. Data are Mean \pm standard error mean. $(\mathrm{n}=7)$; ${ }^{\mathrm{c}} \mathrm{p} \leq 0.001$, $\mathrm{d}$ non-significant as compared to the respective control values, ${ }^{\mathrm{g}} \mathrm{p} \leq 0.001$, and ${ }^{\mathrm{h}} \mathrm{non}$ significant as compared to the respective values of the diabetic control group

Table 2: Effect of T. undulata root extracts on lipid profile in STZ induced diabetic albino rats

\begin{tabular}{|c|c|c|c|c|c|c|}
\hline Groups & Cholesterol & HDL (mg/dl) & LDL (mg/dl) & VLDL (mg/dl) & Triglyceride (mg/dl) & LDL/HDL \\
\hline Group I (vehicle control) & $106.01 \pm 7.23$ & $30.11 \pm 2.10$ & $52.29 \pm 3.16$ & $23.61 \pm 1.96$ & $118.03 \pm 09.31$ & $1.74 \pm 0.02$ \\
\hline Group II (diabetic control) & $235.61 \pm 12.12^{\mathrm{c}}$ & $29.89 \pm 2.23^{\mathrm{d}}$ & $167.92 \pm 6.12^{\mathrm{d}}$ & $37.80 \pm 3.16^{\mathrm{d}}$ & $189.01 \pm 6.67^{\mathrm{a}}$ & $5.62 \pm 0.32^{\mathrm{c}}$ \\
\hline $\begin{array}{l}\text { Group III (T. undulata root } \\
\text { extract treatment) }\end{array}$ & $126.58 \pm 09.73^{\mathrm{c} g}$ & $30.71 \pm 0.32^{\mathrm{d}, \mathrm{h}}$ & $73.33 \pm 0.59^{\mathrm{c}, g}$ & $22.54 \pm 0.23^{\mathrm{chh}}$ & $112.7 \pm 0.62^{\mathrm{c}, \mathrm{f}}$ & $2.29 \pm 0.03^{\mathrm{chh}}$ \\
\hline $\begin{array}{l}\text { Group IV (metformin } \\
\text { treatment) }\end{array}$ & $127.44 \pm 5.11^{\mathrm{c}, \mathrm{f}}$ & $30.17 \pm 0.63^{\mathrm{d}, \mathrm{h}}$ & $75.39 \pm 0.32^{\mathrm{c}, \mathrm{f}}$ & $22.08 \pm 1.07^{\mathrm{chh}}$ & $110.41 \pm 1.7^{\mathrm{cff}}$ & $2.57 \pm 0.17^{\mathrm{chh}}$ \\
\hline
\end{tabular}

Data are means \pm SEM. $(n=7),{ }^{c} p \leq 0.001$, ${ }^{d}$ non-significant as compared to the respective control values, ${ }^{\mathrm{g} p} \leq 0.001$, and ${ }^{\mathrm{h}}$ non-significant as compared to the respective values of the diabetic control group, T. undulate: Tecomella undulate, STZ: Streptozotocin, LDL: Low-density lipoprotein, HDL: High-density lipoprotein, VLDL: Very low-density lipoprotein, ${ }^{\mathrm{a} p} \leq 0.05,{ }^{\mathrm{f} p} \leq 0.01$

caring diabetes and other diseases, but issues of side effects are still questionable. Although natural cures were used and still be used today with minimum side effects. There are many herbs with strong antidiabetic properties by following different mechanisms [32-37]. In the present study, the treatments of root extract of T. undulata performed hypoglycemic effect in gradual reductions in comparison to metformin 


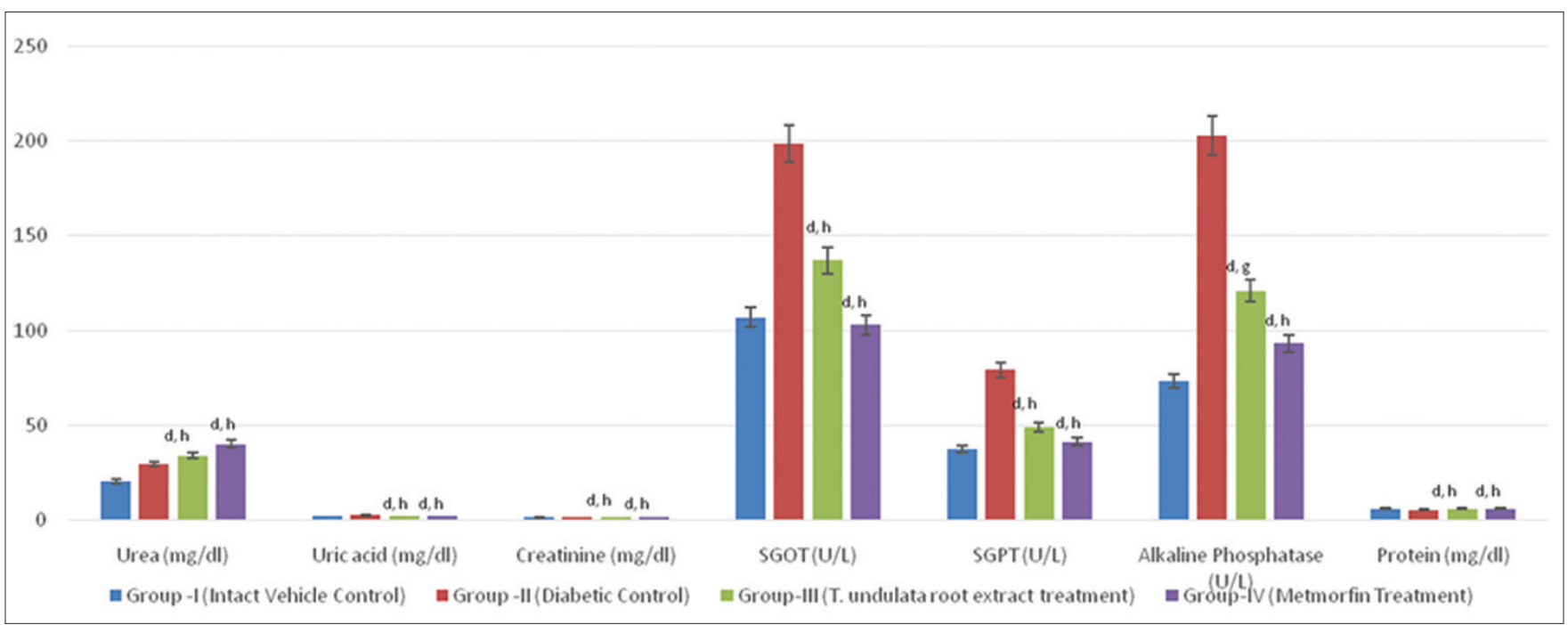

Fig. 3: Haematological assessments of Tecomella undulate root extract treatments in streptozotocin induced diabetic albino rats (mean of 5 value \pm standard error mean [SEM]). Data are means \pm SEM. $(n=7),{ }^{c} p \leq 0.001$, ${ }^{d}$ non-significant as compared to the respective control values, ${ }^{g} \mathrm{p} \leq 0.001$, and ${ }^{\mathrm{h}}$ non-significant as compared to the respective values of the diabetic control group

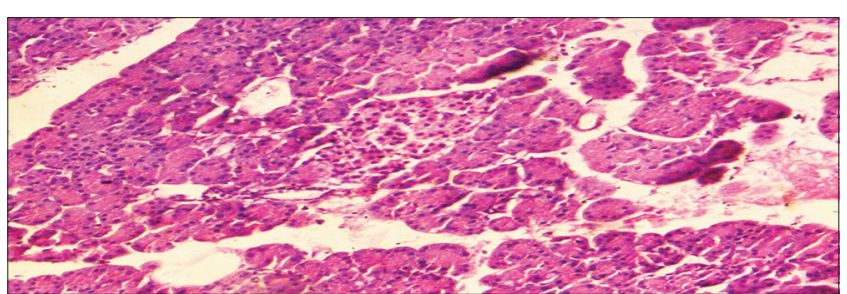

Fig. 4: Pancreatic histoarchitecture of intact vehicle control rats ( $H$ and $E \times 200$ ) - the histoarchitecture of intact vehicle control pancreas exhibiting of islets of Langerhans with cluster of cells organized in asymmetrical departing and anastomosing strings detached by blood capillaries and subtle collagen fibres

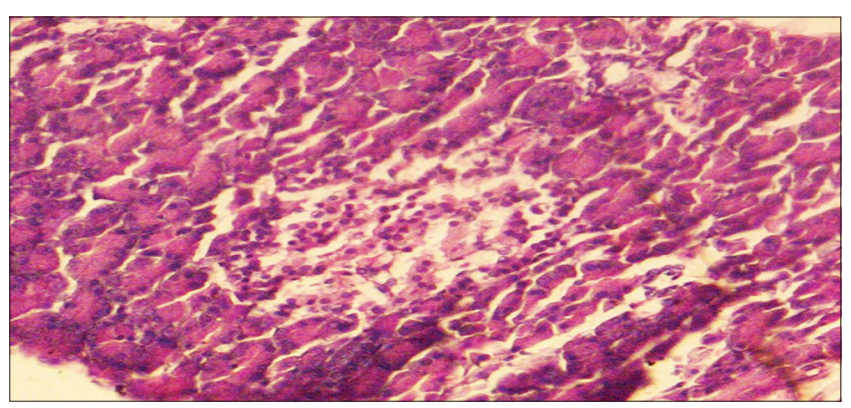

Fig. 5: Pancreatic histoarchitecture of diabetic control rats ( $H$ and $E \times 200$ ) - diabetic pancreatic histoarchitecture containing of vacuolated islets of Langerhans and necrotic nuclei of islet cells with congested blood vessels

standard drug $[13,20,38]$. This type of activity may be conducted through alone or synchronic action of possessing bioactive compounds, i.e., oleanolic acid, ursolic acid, betulinic acid, triacontanol, cirsimaritin, cirilineol, pentariacontanol, 4,5-dihydroxy 3,6,8- trimethoxyflavones, and other phytocompounds as described by earlier researchers. The treatment caused non-significant and significant changes in body and organs weights. The changes in body and organs weights could be following STZ activities and ameliorative actions of phytocompounds against hyperglycemia correspondingly [35,39].

However, there are stated some hypothesis regarding hypoglycemic or insulin mimic effect of plant products as their effects on the activity of pancreatic beta cells, increase in the oppressive action against insulinase enzyme, establishment of the insulin sensitivity or the insulin-like effect of the phytocompounds and through other mechanisms [40]. However, other concept suggested that it might also be involved such as increase of peripheral consumption of glucose, intensification of synthesis of hepatic glycogen or reduction of glycogenolysis, inhibition of intestinal glucose absorption, decrease of glycemic index of glycemic content, and decrease of the consequence of glutathione. In parallel milieu, lipid parameters, i.e., total cholesterol, LDL -cholesterol, triglyceride, and other indices were also reduced which may be due to be lacking in changes of gluconeogenesis and unapproachability of peripheral excess glucose $[41,42]$. Subsequently, the STZ caused a substantial reduction in pancreatic cells and structural fluctuations as stated by some studies $[1,16,42]$. The introduction of STZ caused $\beta$-cell toxicity is rational through carboxylation of proteins, alkylation of DNA, release of free radicals (reactive oxygen species and reactive nitrogen species) and inhibition of O-GlcNAcse (glycoside hydrolase). These types of detrimental actions made by STZ are accountable for necrosis of pancreatic $\beta$-cells and introduction of experimental diabetes mellitus in laboratory animal models. Although the treatments of root extract of T. undulata caused various grades of a renaissance in pancreatic cells and endorsing numerous grade of re-histoarchitecture of pancreas. This kind of action of herbal products also stated by previous studies and illustrations that having bioactive compounds might consume congested more devastation of the enduring $\beta$-cells in the islet by mopping up the circulating reactive oxygen species generated through the STZ to devastate the $\beta$-cells and then permitting additional phytochemicals of the herbal to stimulate regenerative activities [1,43]. The administration of the herbal extract todiabetic animals provoked a decrease in aminotransferases in serum, i.e., SGOT, SGPT, and alkaline phosphatase, a result of experimental and toxicological importance quantified that changes in their actions are pinpointing of tissue impairment by contaminants or signs resultant to hepatic disorders. This declination of SGPT, SGOT, and alkaline phosphatase to their normal levels might be chosen by the absence of alkanes in the extract [43]. Correspondingly, other renal and hepatic parameters were also come to under or around regular ranges which suggested nontoxic nature of $T$. undulata extract. Compassionately, hematological parameters were also persisted under normal ranges which also proven least toxic nature of possessing phytocompounds $[24,26,44]$. Therefore, it is concluded that phytocompounds possessing in root extract of $T$. undulate having potential of glucose homeostatic and pancreatic protection which can be help in therapeutic strategies of diabetes. 


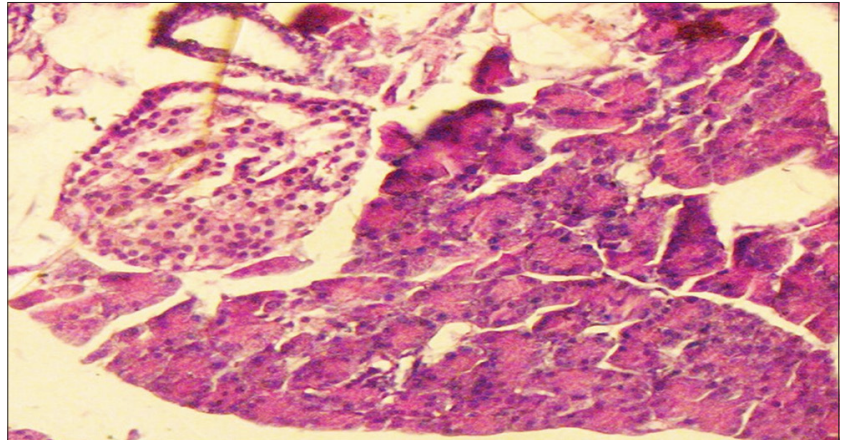

Fig. 6: Pancreatic histoarchitecture of Tecomella undulate root extract $(500 \mathrm{mg} / \mathrm{kg})$ treatment $(\mathrm{H}$ and $\mathrm{E} \times 200)$ - the pancreatic histoarchitecture containing of acini and regenerated cellular portion of islets of Langerhans with appropriate distribution of blood vessels

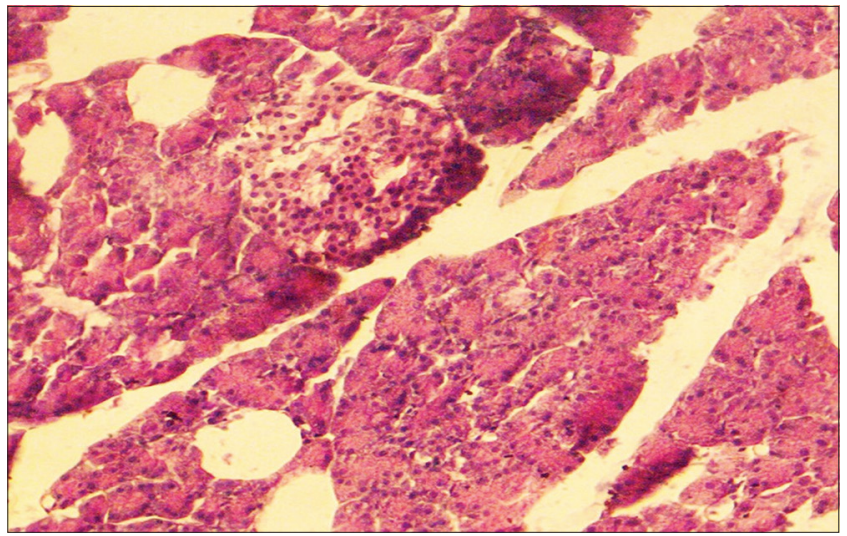

Fig. 7: Pancreatic histoarchitecture of metformin treatment ( $H$ and $E \times 200$ ) - the pancreatic histoarchitecture comprising of acini and regenerated cellular portion of islets of Langerhans with appropriate distribution of blood vessel

\section{CONCLUSION}

From the finding of this study, it can be concluded that the root extract of T. undulata consisting numerous bioactive chemicals, which shows a glucose homeostatic and pancreas protective potential. This study will be beneficial in additional compounds level can be elaborate more utility of this plant product which can verify it as potent cost-effective antidiabetic agent from native resources using conventional wisdom.

\section{ACKNOWLEDGMENT}

In this study, we would like to acknowledge our research team and their scientific contribution.

\section{REFERENCES}

1. Akbarzadeh A, Norouzian D, Mehrabi MR, Jamshidi SH, Farhangi A, Verdi AA, et al. Induction of diabetes by Streptozotocin in rats. Indian J Clin Biochem 2007;22:60-4.

2. Goldman-Levine J. An overview of glycemic goals and medications used to manage Type 2 diabetes. Nutr Today 2016;50(1):40-8.

3. White JR Jr. A brief history of the development of diabetes medications. Diabetes Spectr 2014:27(2):82-6.

4. Yin J, Zhang H, Ye J. Traditional chinese medicine in treatment of metabolic syndrome. Endocr Metab Immune Disord Drug Targets 2008;8(2):99-111.

5. Modak M, Dixit P, Londhe J, Ghaskadbi S, Devasagayam TP. Indian herbs and herbal drugs used for the treatment of diabetes. J Clin Biochem Nutr 2007;40(3):163-73.

6. Ahlawat J, Verma N, Sehrawat AR. Globalisation of herbal drugs: A bliss and concern. Int J Sci Res 2014;3(11):466-74.
7. Talaviya PA, Rao SK, Vyas BM, Indoria SP, Rakesh K, Suman RK, et al. Review on: Potential antidiabetic herbal medicines. Int J Pharm Sci Res 2014;5(2):302-19.

8. Arockia JA, Mohan VR, Doss A. Antidiabetic activity of Bacolepis nervosa (Wight and Arn.) Decne. Ex moq. Extract on alloxan induced diabetic rats. Int J Pharm Pharm Sci 2016;8(11):320-6.

9. Abubakar US, Abdullahi S, Ayuba V, Kaigama S, Halidu US, Ayuba MK. Medicinal plants used for the management of diabetes mellitus in Zaria, Kaduna state, Nigeria. J Pharm Pharmacogn Res 2017;5(3):156-64.

10. Patel DK, Prasad SK, Kumar R, Hemalatha S. An overview on antidiabetic medicinal plants having insulin mimetic property. Asian Pac J Trop Biomed 2012;2(4):320-30.

11. Oboh G, Agunloye OM, Adefegha SA, Akinyemi AJ, Ademiluyi AO. Caffeic and chlorogenic acids inhibit key enzymes linked to Type 2 diabetes (in vitro): A comparative study. J Basic Clin Physiol Pharmacol 2015;26(2):165-70

12. Harlev E, Nevo E, Mirsky N, Ofir R. Antidiabetic attributes of desert and steppic plants: A review. Planta Med 2013;79(6):425-36.

13. Das T, Das B, Saha D, Mishra SB. Anti-hyperglycemic effect of Tecomella undulata extract by ameliorating pancreatic dysfunction in streptozotocin induced diabetic albino rats. J Appl Pharm Sci 2015;5(11):90-4.

14. Dhir R, Shekhawat GS. Research article critical review on Tecomella undulata: A medicinally potent endangered plant species of Indian thar desert. Int J Curr Res 2012;4(6):36-44.

15. Srivastava S, Choudhary GP. Phytochemistry and pharmacological activity of Tecomella undulata: An overview. Mintage J Pharm Med Sci 2014;3(3):27-30.

16. Lal K, Purohit A, Ram H. Insulin mimetic and pancreas-protective effect of Tecomella undulata leaves extract in diabetic rats. World J Pharm Pharm Sci 2017;6(2):924-38.

17. Jain M, Kapadia R, Jadeja RN, Thounaojam MC, Devkar RV, Mishra SH. Traditional uses, phytochemistry and pharmacology of Tecomella undulata - A review. Asian Pac J Trop Biomed 2012;1691(12):60521-8.

18. Kumar S, Sharma S, Vasudeva N, Ranga V. In vivo anti-hyperglycemic and antioxidant potentials of ethanolic extract from Tecomella undulata. Diabetol Metab Syndr 2012;4(33):1-7.

19. Kumawat R, Sharma S, Kumar S. An overview for various aspects of multifaceted, health care Tecomella undulata seem. Plant. Acta Pol Pharm 2012;69(5):993-6

20. Rohilla R, Garg C, Garg M. In vitro hypoglycemic evaluation of fractions of hydroalcoholic extract of heartwood of Tecomella undulata Linn. Asian J Pharm Clin Res 2017;10(2):266-9.

21. Sovia E, Ratwita W, Wijayanti D, Novianty DR. Hypoglycemic and hypolipidemic effects of Annona muricata L. Leaf ethanol extract. Int J Pharm Pharm Sci 2016;9(3):170-4.

22. El-Sawi N, Gad MH, Al-Seeni MN, Younes S, El-Ghadban M, Ali SS. Evaluation of antidiabetic activity of Ipomoea aquatica fractions in streptozotocin induced diabetic in male rat model. Sohag J Sci 2017;2(1):9-17.

23. Arya A, Al-Obaidi MM, Shahid N, Bin Noordin MI, Looi CY, Wong WF, et al. Synergistic effect of quercetin and quinic acid by alleviating structural degeneration in the liver, kidney and pancreas tissues of STZ-induced diabetic rats: A mechanistic study. Food Chem Toxicol 2014;71:183-96.

24. Vyas A, Ram H, Purohit A, Jatwa R. Adverse effects of subchronic dose of aspirin on reproductive profile of male rats. J Pharm (Cairo) 2016;2016:6585430

25. Bidkar JS, Ghanwat DD, Bhujbal MD, Dama GY. Anti-hyperlipidemic activity of Cucumis melo fruit peel extracts in high cholesterol diet induced hyperlipidemia in rats. J Complement Integr Med 2012;9:1-6.

26. Arika WM, Nyamai DW, Musila MN, Ngugi MP, Njagi EN. Hematological markers of in vivo toxicity. Hematol Thrombo Dis 2016;4(2):1-6.

27. Al-Qudah MM, Haddad MA, EL-Qudah JM. The effects of aqueous ginger extract on pancreas histology and on blood glucose in normal and alloxan monohydrate-induced diabetic rats. Biomed Res 2016;27(2):350-6.

28. Mohammad W, Hamed A, Abid KY, Al-Amin SA. Hypoglycemic and hypolipidemic effects of grapefruit juice in diabetic rats. Tikrit J Pure Sci 2008;13(1):129-31.

29. Ojiako OA, Chikezie PC, Ogbuji AC. Blood glucose level and lipid profile of alloxan-induced hyperglycemic rats treated with single and combinatorial herbal formulations. J Tradit Complement Med 2016;6:184-92.

30. Olaniyan J, Muhammad H. Acute and sub-acute toxicity studies of aqueous and methanol extracts of Nelsonia campestris in rats. J Acute 
Dis 2015;5(1):62-70.

31. Parmar HS, Bhinchar MK, Bhatia M, Chordia N, Raval I, Chauhan DS, et al. Study on gluco-regulatory potential of glimepiride sulfonamide using in silico, in vitro and in vivo approaches. Curr Pharm Des 2014;20:5212-7.

32. Patnaik PK, Jain KK, Chandra P, Pathak J, Raman KV, Shah A. Diabetes in India: Measuring the dynamics of a public health catastrophe. J Soc Health Diabetes 2016;4(2):77-84.

33. Prabhakar PK, Doble M. Mechanism of action of natural products used in the treatment of diabetes mellitus. Chin J Integr Med 2011;17:563-74.

34. Rao BG, Raju NJ. Investigation of hepatoprotective activity of Spondias pinnata. Int J Pharm Sci Res 2010;1(3):193-8.

35. Zafar M, Naqvi SN. Effects of STZ-induced diabetes on the relative weights of kidney, liver and pancreas in albino rats: A comparative study. Int J Morphol 2010;28(1):135-42.

36. Wen L, Zhang Y, Sun-Waterhouse D, You L, Fu X. Advantages of the polysaccharides from Gracilaria lemaneiformis over metformin in antidiabetic effects on streptozotocin-induced diabetic mice. RSC Adv 2017;7:9141-51.

37. Trilochana Y, Babu DJ, Rao PR. The study of anti-diabetic activity of aqueous extract of root of Gynandropsis gynandra in diabetic rats. Indian J Res Pharm Biotech 2017;5(1):13-8.

38. Njangiru IK, Gitimu MR, Njagi EN. In vivo antidiabetic activity of aqueous extract of Psidium quajava in alloxanised diabetic mice. J Med Biomed Appl Sci 2017;5(1):1-6.

39. Jemaa HB, Jemia AB, Khlifi S, Ahmed HB, Slama FB, Benzarti A, et al. Antioxidant activity and $\alpha$-amylase inhibitory potential of Rosa canina L. Afr J Tradit Complement Altern Med 2017;14(2):1-8.

40. Cheng JT, Huang CC, Liu IM, Tzeng TF, Chang CJ. Novel mechanism for plasma glucose-lowering action of metformin in streptozotocininduced diabetic rats. Diabetes 2006;55(3):819-25.

41. Fattahi A, Niyazi F, Shahbazi B, Farzaei MH, Bahrami G. Antidiabetic mechanisms of Rosa canina fruits: An in vitro evaluation. J Evid Based Complementary Altern Med 2017;22:127-33.

42. Lo HY, Li TC, Yang TY, Li CC, Chiang JH, Hsiang CY, et al. Hypoglycemic effects of Trichosanthes kirilowii and its protein constituent in diabetic mice: The involvement of insulin receptor pathway. BMC Complement Altern Med 2017;17(1):53

43. Ahmed R, Ramayya PJ, Raju NK, Kumar RV, Rao SD. Microscopic studies on islets of langerhans of pancreas of adult albino rat. Indian $\mathrm{J}$ Vet Anat 2014;26(2):97-8

44. Naik SR, Thakare VN, Patil SR. Protective effect of curcumin on experimentally induced inflammation, hepatotoxicity and cardiotoxicity in rats: Evidence of its antioxidant property. Exp Toxicol Pathol 2011;63(5):419-31 